\title{
IMPLEMENTASI PENGEMBANGAN MATERI PAI MI PERSPEKTIF INTEGRASI INTERKONEKSI
}

\author{
Ali Imron \\ Universitas Wahid Hasyim \\ aliimron.aya@gmail.com
}

\begin{abstract}
Abstrak
Fenomena dikotomi bidang keilmuan yakni antroposentris dan teosentris menjadi fakta sejarah. Pendidikan antroposentris penting untuk pembinaan dan penyempurnaan kepribadian anak. Sedangkan pendidikan teosentris/sain (ilmu non agama-teosentris) juga dibutuhkan untuk melengkapi pengetahuannya. Keberadaannya dianggap sebagai pelengkap, sehingga umat Islam mengesampingkan ilmu non agama atau sebaliknya. Hal ini mengakibatkan umat Islam terbelakang dalam hal sains dan teknologi. Pengembangan materi PAI MI persepektif integrasi interkoneksi baik internal maupun eksternal dapat menjadi salah satu tawaran model pengembangan materi guna membekali pengetahuan yang komprehensif, sebab Islam tidak pernah menganggap adanya dikotomi ilmu pengetahuan (sain) dan agama.
\end{abstract}

Kata Kunci : dikotomi, materi PAI MI, Integrasi, Interkoneksi.

\begin{abstract}
Abstact
Dichotomy phenomenon devided into 2 parts in science, they are antropocentris and teocentris which are called history fact. Antropocentris education is very important to construct and to complete students personality. Science education (non religion-teocentris science) also needed by Moslem generation to complete their knowledge. Its existance considered as complement, so Moslems put a side non-religion science or on contrary. It makes Moslem left behind in science and technology. Material development for Islamic Education in MI in perspective integrative interconnection both internal or external can be one of offered material development model to give comprehensive science for students in MI, because Islam never consider science and religion dichotomy.
\end{abstract}

Keywords: dichotomy, material for Islamic education in MI, interconnection 


\section{A. PENDAHULUAN}

Pendidikan merupakan aspek universal yang selalu dan harus ada dalam kehidupan manusia. Tanpa ada pendidikan, manusia tidak akan pernah mendapat kebudayaan, jika tanpa pendidikan kehidupan manusia tentu akan mengarah pada kehidupan statis, tanpa ada kemajuan, bahkan bisa jadi akan mengalami kemunduran dan kepunahan. Karena itu, menjadi fakta yang tak terbantahkan bahwa pendidikan adalah sesuatu yang niscaya dalam kehidupan manusia.

Pendidikan merupakan kunci untuk menapaki masa depan, artinya pendidikanlah yang menentukan arah kehidupan manusia. Sedemikian pentingnya pendidikan ini dalam hidup, maka pendidikan selalu menjadi ranah yang hangat untuk diperbincangkan. Hal yang menarik lagi dalam diskursus dikotomi keilmuan adalah pijakan akar budaya dan historisitas dari perkembangan pendidikan di Indonesia. Suatu kondisi yang tidak boleh tidak ada seandainya kita mau meneliti tentang perkembangan pendidikan di negeri kita ini adalah faktor kesejarahan. Bagaimanapun juga sejarah warisan kolonial Belanda turut membentuk wajah pendidikan Indonesia.

Secara leksikal dalam Kamus Besar Bahasa Indonesia, dikotomi mempunyai pengertian sebagai pembagian atas dua kelompok yang saling bertentangan. ${ }^{1}$ Sedangkan dalam arti lain, dikotomi diartikan sebagai pembagian atas dua konsep yang saling bertentangan. ${ }^{2}$ Dengan demikian dikotomi adalah segala hal yang membagi sesuatu menjadi dua kelompok yang berbeda bahkan saling

1 Tim Penyusun Kamus Pusat Bahasa, Kamus Besar Bahasa Indonesia, Jakarta: Balai Pustaka, 2001, hlm. 264. hlm. 74 .

2 Mujammil Qamar, Epistemologi Pendidikan Islam, Jakarta: Erlangga, 2006, 
bertentangan antara kelompok tersebut. Berarti pengertian dikotomi ilmu adalah membedakan, memisah kanilmuan menjadi dua kelompok atau dua bagian yang saling berbeda dan bertentangan.

Istilah dikotomi ilmu adalah sikap atau paham yang membedakan, memisahkan, dan mempertentangkan antara ilmu-ilmu agama dan ilmu-ilmu non agama (ilmu umum). Beberapa diantaranya adalah ilmu akhirat dan ilmu dunia. Ada juga yang menyebutnya dengan ilmu syar'iyyah dan ilmu ghairu syar'iyyah, bahkan ada juga sebutan lainnya seperti al-'ulum al-diniyyah dan al-'ulum al'aqliyyah. Dalam istilah bahasa Inggris perbedaan kata yang dipakai dikenal dengan Islamic Knowledge dan Non Islamic Knowledge. ${ }^{3}$ Adapun sikap atau keadaan yang bersifat memisahkan, membedakan, dan mempertentangkan ilmu ke dalam ilmu agama dan ilmu non agama disebut dengan sikap dikotomis terhadap ilmu.

Secara klasifikasi, memang mereka membedakan keduanya, akan tetapi secara prinsip mereka memposisikan dalam status dan kedudukan yang sama, sehingga keduanya mendapat porsi yang sama untuk dieksplorasi, menyebabkan adanya interaksi simbiosismutualisme antara kedua ranah ilmu tersebut. Artinya, antara satu dengan yang lainnya bukan merupakan anti thesis terhadap yang lainnya, namun beriringan menjadi "dwi-tunggal" yang saling memberikan kontribusi.

Pandangan dan sikap keilmuwan di zaman Nabi Muhammad SAW yang memposisikan ilmu secara parallel tersebut menyebabkan eksplorasi terhadap ilmu selain ilmu agama sudah mulai dilakukan meskipun dalam kadar yang sangat sederhana. Bahkan nabi

\footnotetext{
${ }^{3}$ Ahmad Asy'ari dan Rusnil Bil Makruf, Dikotomi Prndidikan Islam, elHikmah Jurnal kajian dan Penelitian Pendidikan Islam, Vol.8 No.2 Desember 2014, hlm. 9.
} 
Muhammad tidak pernah mengajarkan kepada pengikutnya yang beriman dan bertaqwa untuk menjauhi dunia yang merupakan media dalam menggapai kesempurnaan hidup. Nilai-nilai ini tampak pada waktu Islam lahir pada pertengahan pertama abad ke-7 M, bangsa Arab dikelilingi oleh bangsa-bangsa yang memiliki kebudayaan tinggi dan megah, seperti Persia, Romawi, Yunani, dan India. ${ }^{4}$ Sudah ada semacam ilmu yang kemudian sedikit banyak mempengaruhi terhadap perkembangan ilmu agama Islam.

Adanya anggapan bahwa terdapat dikotomi antara ilmu agama dan Ilmu umum. Abd. Rachman Assegaf mengungkapkan beberapa hal yang menjadi penyebab terjadinya dikotomi ilmu ini, yakni: 1) faktor perkembangan pembidangan ilmu, 2) faktor historis perkembangan umat Islam ketika mengalami masa kemunduran sejak Abad Pertengahan, 3) faktor internal kelembagaan pendidikan Islam yang kurang mampu melakukan upaya pembenahan dan pembaruan. Mengenai faktor yang ketiga, Abd. Rachman Assegaf lebih lanjut menggungkapkan bahwa hal tersebut kemudian berakibat pada munculnya anggapan bahwa madrasah mewakili lembaga pendidikan agama, sedangkan sekolah umum merupakan wadah bagai pendidikan (umum) umat. 5

Prof. Sutrisno mengungkapkan akibat dari sistem pendidikan yang dikotomis adalah lahirnya pribadi - pribadi dengan standar moral ganda, misalnya seorang muslim yang taat beribadah namun pada saat yang lain juga melakukan korupsi, menindas, dan melakukan

${ }^{4}$ Ahmad Asy'ari dan Rusnil Bil Makruf, Dikotomi Prndidikan Islam, elHikmah Jurnal kajian dan Penelitian Pendidikan Islam, Vol.8 No.2 Desember 2014, hlm. 6.

5 Abd. Rachman Assegaf "Pengantar" dalam: Jasa Ungguh Muliawan, Pendidikan Islam Integratif, Yogyakarta: Pustaka Pelajar, 2005, hlm. vii-X.

117 MAGISTRA - Volume 8 Nomor 2 Desember 2017 
perbuatan tercela6. Pada masa Menag Mukti Ali, muncul SKB tiga Menteri yang berimplikasi pada meningkatnya porsi pengetahuan umum di madrasah menjadi $70 \%$ pengetahuan umum dan $30 \%$ pengetahuan agama. Menanggapi hal tersebut, Muhaimin mengungkapkan bahwa SKB tersebut masih sering dipahami secara simbolik kuantitatif oleh pengelola madrasah, sehingga justru membuat lulusan mandul baik ilmu umum, maupun agamanya ${ }^{7}$.

Faham dikotomi ilmu atau pendidikan ini akan membawa dampak terjadinya disintegrasi sistem pendidikan yaitu tidakpadu dan tidakpasti hubungan antara pendidikan umum dan pendidikan agama. Di dalam memandang ke dua ilmu tersebut tidak adanya persamaan dalam menilai, lebih cenderung akan ada salah satu yang menjadi tujuan pokok suatu lembaga pendidikan dalam melaksanakan proses pembelajaran. Kedua ilmu tersebut tidak dapat berjalan beriringan dan menjadi satu kesatuan yang padu.

Islam memiliki faham ajaran integralistik yang mengajarkan bahwa urusan dunia tidak terpisahkan dengan urusan akhirat, akan tetapi merupakan satu kesatuan. Oleh karena itu, ilmu-ilmu umum harus dipahami sebagai bagian yang integral dari ilmu- ilmu agama. ${ }^{8}$ Agama Islam tidak melarang kita untuk mempelajari ilmu-ilmu umum. Untuk kebutuhan hidup kita di dunia, maka kita pun harus mempelajari, mengetahui, lalu mengaplikasikannya dalam kehidupan sehari-hari, dengan tujuan untuk membantu kita dalam hidup di dunia yang akan menghantarkan untuk kehidupan di akhirat.

${ }^{6}$ Sutrisno, Pendidikan Islam Yang Menghidupkan, Cet II, Yogyakarta: Kota Kembang, 2008, hlm. 3.

${ }^{7}$ Muhaimin, Wacana Pengembangan Pendidikan Islam, Cet II, Yogyakarta: Pustaka Pelajar, 2004, hlm. 176.

${ }^{8}$ M. Zainuddin. Paradigma Pendidikan Terpadu, Menyiapkan Generasi Ulul Albab, Malang: UIN-Malang Press, 2008, hlm 31

118 MAGISTRA - Volume 8 Nomor 2 Desember 2017 
Oleh sebab itu untuk menghindari terjadi kesenjangan yang tidak berkesudahan maka dianggap penting untuk mencarikan berbagai macam tawaran solusi dalam pengembangan materi di MI. Salah satu tawaran untuk menghilangkan adanya dikotomi dalam pembelajaran adalah dengan menerapkan pengembangan materi PAI MI persepektif Integratif Interkonektif di MI.

\section{B. PEMBAHASAN}

\section{Integrasi-Interkoneksi Materi PAI di MI}

\section{a. Pengertian Integrasi-interkoneksi}

Integrasi-interkoneksi merupakan upaya untuk mempertemukan antara ilmu-ilmu agama (Islam) dan ilmu-ilmu umum (sains-teknologi dan sosial-humaniora). ${ }^{9}$ Model pembelajaran integratif (terpadu) menawarkan sebuah pemahaman yang holistik (menyeluruh) sebagaimana yang tercantum pada PP no. 19 tahun 2005 tentang Standar Nasional Pendidikan dinyatakan bahwa setiap kelompok mata pelajaran (KMP) dilaksanakan secara holistik sehingga pembelajaran masing-masing KMP mempengaruhi pemahaman atau penghayatan peserta didik. Mengkombinasikan beberapa hal sedemikian rupa dimana beberapa hal tersebut membentuk sebuah kesatuan. Tujuannya dalam membuat suatu jalinan (hubungan) sehingga pemahaman anak (peserta didik) mencakup dua atau beberapa subjek seolah-olah dia adalah satu. 10

9 Pokja Akademik UIN Sunan Kalijaga,2004.

10 ANN C. HOWE \& Linda Jones, Children In science; (Integrating Science With Other Subjects),N ew York: Macmillan Publishing Company, 1993, hlm. 219230.

119 MAGISTRA - Volume 8 Nomor 2 Desember 2017 
Islam tidak pernah menganggap adanya dikotomi ilmu pengetahuan dan agama. Ilmu pengetahuan dan agama merupakan satu totalitas yang integral yang tidak dapat dipisahkan satu dengan yang lainnya. Sesungguhnya Allahlah yang menciptakan akal bagi manusia untuk mengkaji dan menganalisis apa yang ada dalam alam ini sebagai pelajaran dan bimbingan bagi manusia dalam menjalankan kehidupannya di dunia. Uraian di atas menggambarkan kepada kita bahwa dalam ilmu pengetahuan agama dan ilmu pengetahuan umum merupakan satu kesatuan yang tidak terpisahkan antara satu dengan yang lainnya dalam menjalankan aktivitas kehidupan sehari-hari.

Kedua ilmu tersebut harus dimiliki secara integral, agar fungsi manusia sebagai abid dan kholifah dapat terlaksana dengan maksimal. Untuk menciptakan system pendidikan yang terpadu yang mampu mengakomodir seluruh potensi peserta didik dengan utuh, sehingga menghasilkan manusia yang paripurna (insankamil), maka perlu adanya keterpaduan yang harmonis dalam semua komponen pendidikannya.

Menurut Prabowo dalam Melani Kasim, pembelajaran terpadu merupakan pendekatan belajar mengajar yang melibatkan beberapa bidang studi. Pendekatan belajar mengajar seperti ini diharapkan akan dapat memberikan pengalaman yang bermakna kepada anak didik kita. Arti bermakna disini dikarenakan dalam pembelajaran terpadu diharapkan anak akan memperoleh pemahaman terhadap konsep-konsep yang mereka pelajari dengan melalui pengalaman langsung dan 
menghubungkannya dengan konsep lain yang sudah mereka pahami. ${ }^{11}$

\section{b. Konsep Dasar Integrasi-Interkoneksi Materi PAI MI}

Integratif adalah keterpaduan kebenaran wahyu dengan bukti-bukti yang ditemukan di alam semesta. Struktur keilmuan yang integratif disini tidak berarti antara berbagai ilmu tersebut dilebur menjadi satu bentuk ilmu yang identik, melainkan karakter, corak, dan hakikat antara ilmu tersebut terpadu dalam kesatuan dimensi material-spiritual, akal-wahyu, ilmu umumilmu agama, jasmani-rohani, dan dunia-akhirat. Interkoneksitas adalah keterkaitan satu pengetahuan dengan pengetahuan yang lain akibat adanya hubungan yang saling mempengaruhi. ${ }^{12}$ Maya Fitria, mengemukakan pendapatnya mengenai paradigma keilmuan integrasi interkoneksi bahwa "secara pasti, paradigma ini dapat ditegaskan sebagai sebuah proses penyatuan antara ilmu dengan agama (Islam)".13 Dari sini asumsi yang dapat diajukan sebagai konsep dasar integrasi interkoneksi ialah bahwa ilmu itu satu.

Mengutip pendapat Azyumardi Azra, Jasa Ungguh Muliawan mengatakan bahwa perdebatan dikotomi ilmu dalam pemikiran Islam, yaitu pertentangan dikotomi ilmu dengan istilah kelompok ilmu "antroposentris" dihadapkan dengan

11 Melani Kasim, Pembelajaran Terpadu, Makalah "Pembelajaran Terpadu" «Meilanikasim's Blog.htm.

12 Abd. Rachman Assegaf "Pengantar" dalam: Jasa Ungguh Muliawan, Pendidikan Islam Integratif, Yogyakarta: Pustaka Pelajar, 2005, hlm.Xii.

13 Maya Fitria, Psikologi Integrasi Interkoneksi, dalam Keilmuan, Integrasi dan Interkoneksi Bidang Agama dan Sosial, Yogyakarta: Lembaga Penelitian UIN Sunan Kalijaga, 2007, hlm. 369.

121 MAGISTRA - Volume 8 Nomor 2 Desember 2017 
kelompok ilmu "teosentris" dapat dijelaskan berdasarkan konsep kesatuan ilmu Islam. ${ }^{14}$ Jika diukur berdasarkan tingkat kedekatannya dengan realitas kenyataan, maka ilmu pengetahuan teosentris lebih jauh rentang jaraknya dengan realitas kenyataan dibandingkan ilmu pengetahauan antroposentris, ilmu pengetahuan teosentris bersifat absolut, mutlak, dan teoritis. ${ }^{15}$

Di madrasah, ilmu antroposentris tersebut terwujud dalam pengetahuan umum sedangkan ilmu teosentris terwujud dalam pengetahuan agama. Dengan konsep kesatuan ilmu Islam, porsi kurikulum 30\% pengetahuan agama dan 70\% pengetahuan umum hendaknya dapat membawa madrasah menjadi lebih diperhitungkan dalam pembangunan dan pendidikan nasional. Porsi kurikulum seperti ini dapat menjadi pijakan untuk melengkapi ilmu islam yang sebelumnya masih didominasi pengetahuan agama dengan pengetahuan umum. Pengetahuan agama menjadi landasan keilmuan Islam di madrasah yang menekankan pada nilai spiritual (iman, aqidah dan untuk membentuk pribadi Islami).

Sedangkan pengetahuan umum (Sain/IPA) dapat menjadi landasan keilmuan Islam yang mendukung secara empiris terhadap nilai spiritual tersebut. Hal ini senada dengan apa yang diungkapkan M. Quraish Shihab, bahwa sains dan hasil-hasilnya harus selalu mengingatkan manusia terhadap kehadiran dan Kemahakuasaan Allah, selain juga harus memberi manfaat bagi

14 Jasa Ungguh Muliawan, Pendidikan Islam Integratif, Yogyakarta: Pustaka Pelajar, 2005, hlm. 209.

15 Ibid. hlm 209.

122 MAGISTRA - Volume 8 Nomor 2 Desember 2017 
kemanusiaan sesuai dengan prinsip bismi Rabbik ${ }^{16}$. Untuk dapat mewujudkan hal itu, maka integrasi dan interkoneksi antara materi PAI - Sain/IPA MI perlu dilakukan.

Pengetahuan agama menekankan pada nilai spiritual. Hal ini sesuai dengan tujuan pendidikan agama dimaksudkan untuk peningkatan potensi spiritual dan membentuk peserta didik agar menjadi manusia yang beriman dan bertakwa kepada Tuhan Yang Maha Esa dan berakhlak mulia. Akhlak mulia mencakup etika, budi pekerti, dan moral sebagai perwujudan dari pendidikan Agama. Penanaman nilai-nilai normatif (Islam) dalam pengembangan keilmuan ini sangat penting. Kaitannya dengan kajian integrasi-interkoneksi ilmu, nilai spiritual dapat menjadi rambu-rambu normatif dari aktivitas ilmiah.

Aktivitas ilmiah yang menjadi titik tolak kemajuan ilmu pengetahuan dan teknologi tanpa rambu-rambu normatif akan bergerak tanpa kendali, bahkan menjadi melenceng dari yang seharusnya berjalan untuk kesejahteraan manusia menjadi menyengsarakan manusia. Hal ini telah lama menjadi kekhawatiran dari para filosof. Terhadap kecemasan ini, Rizal Mustansyir dan Misnal Munir mengemukakan beberapa alasannya, yakni alasan historis, “anak-anak Renaissance yang memisahkan antara aktivitas ilmiah dengan nilai-nilai keagamaan di masa lalu menjadikan ilmu bergerak tanpa kendali dan kering dari rambu-rambu normatif". Kedua; alasan normatif, “orientasi akademik mengalami pergeseran dari wilayah keilmuan ke wilayah pasar yang cenderung profit oriented, hlm. 445 .

16 M. Quraish Shihab, Wawasan Al-Qur'an, Cet III, Bandung: Mizan, 1996, 123 MAGISTRA - Volume 8 Nomor 2 Desember 2017 
sehingga demi uang segolongan ilmuan tak segan-segan melanggar kode etik ilmiah". ${ }^{17}$

Dari uraian di atas, beberapa hal yang dapat digarisbawahi sebagai konsep integrasi interkoneksi ilmu khususnnya yang dapat dilakukan di MI yakni:

a) Islam tidak mengenal dikotomi ilmu, yang berarti ilmu pada dasarnya adalah satu.

b) Pengetahuan agama dan pengetahuan umum yang ada di madrasah perlu diintegrasikan dan diinterkoneksikan agar ilmu yang didapat anak didik menjadi 'utuh'. integarasi dan interkoneksi tersebut dapat dilakukan dengan mengembangkan kurikulum (materi/SK-KD), baik PAI maupun Sain.

c) Mata pelajaran PAI dikembangkan untuk menanamkan nilai spiritual dalam diri peserta didik yang dapat menjadi ramburambu normatif dari kajian ilmiah Sain/IPA. Sedangkan mata pelajaran Sain/IPA dikembangkan sebagai tinjauan ilmiah terhadap materi PAI yang sering bersifat normatif. Dengan begitu, pengembangan materi PAI MI dari perspektif integrasi interkoneksi adalah merekayasa pembelajaran agar dapat memadukan antara kebenaran agama dengan kebenaran empiris, serta mencari keterkaitan yang saling mempengaruhi antar materi/SK-KD dari mata pelajaran yang ada, melalui pengembangan silabus PAI MI. Konsep integrasi interkoneksi ini dapat dilihat pada bagan berikut.

${ }^{17}$ Rizal Mustansyir dan Misnal Munir, Filsafat Ilmu, Cet IX, Yogyakarta: Pustaka Pelajar, 2009, hlm.5 


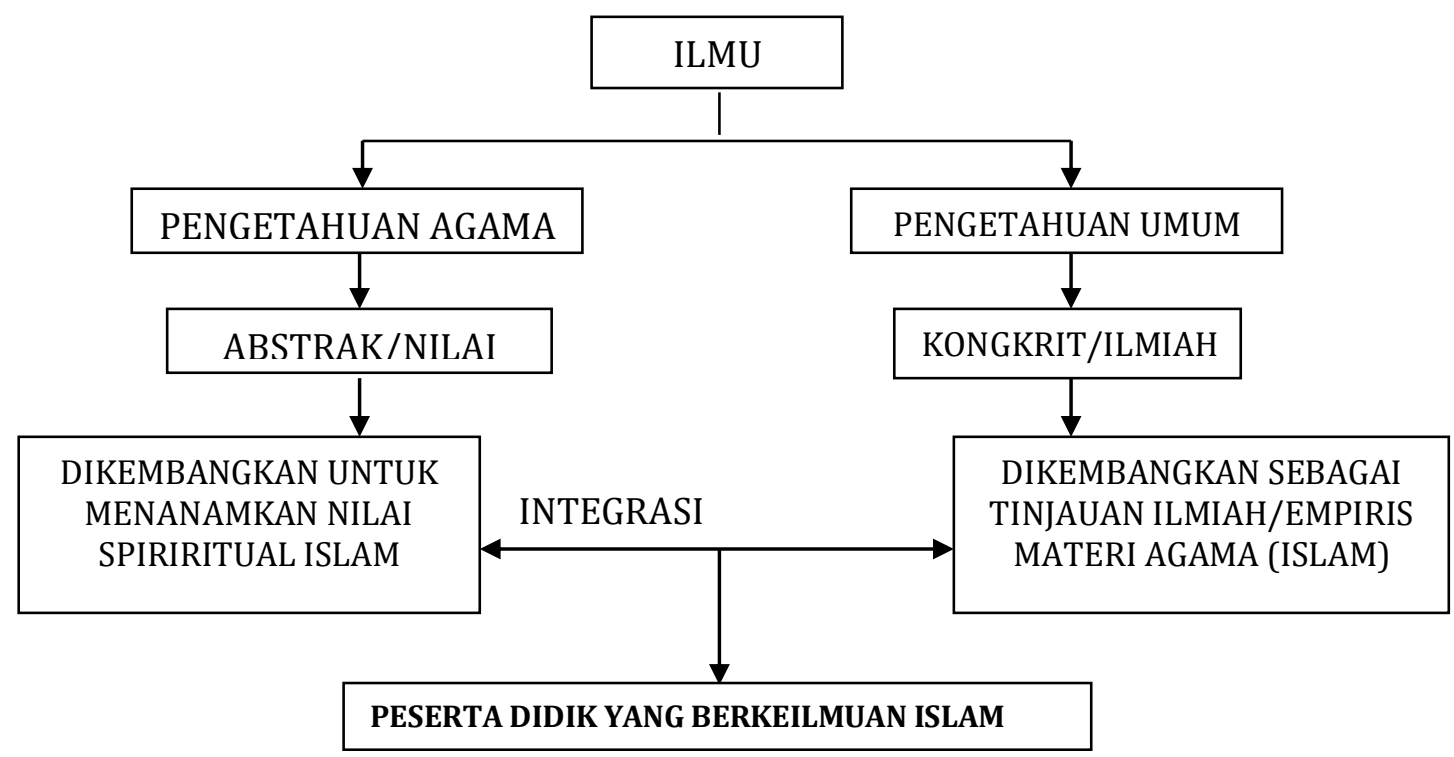

Pengembangan materi PAI MI dari perspektif integrasiInterkoneksi dapat diklasifikasikan menjadi dua, yakni internal dan eksternal. Integrasi interkoneksi internal dilakukan dengan memadukan atau mencari titik temu diantara mata pelajaran yang ada dalam rumpun PAI. Ada lima mata pelajaran dalam rumpun PAI, yakni; Qur'an, Aqidah, Akhlak, Fiqih dan Tarikh.

Tujuan integrasi interkoneksi internal ini adalah untuk membantu peserta didik mendapatkan pemahaman yang terpadu terhadap kelima mata pelajaran tersebut. Dengan begitu nilainilai spiritual (Islam) anak didik sebagai seorang muslim dapat dicapai secara utuh. Misalnya saja, anak didik tidak sekedar mempercayai Allah SWT sebagai Tuhan Yang Maha Esa (Aqidah), tetapi juga mampu melakukan sholat dengan baik (Fiqih) sebagai wujud kepercayaannya tersebut, mampu melafalkan surat-surat yang dibaca dalam sholat dengan fasih (Qur'an). Selain saleh secara spiritual, anak didik juga 'saleh secara sosial' dengan 
berprilaku terpuji (Akhlak), dengan meneladani perilaku Nabi Muhammad atau sahabat Nabi (Tarikh) yang kuat tidak saja pada segi ritual tetapi juga sosial.

Sedangkan secara eksternal integrasi-interkoneski dilakukan antar materi dalam rumpun PAI dengan materi dalam mata pelajaran Sain. Dengan integrasi-interkoneksi eksternal ini, kebenaran wahyu yang ada dalam PAI diharapkan dapat didukung dengan tinjauan ilmiah yang ada dalam materi Sain/IPA. Jika hal ini dapat dilakukan maka diharapkan anak didik akan semakin kuat nilai spiritual Islamnya dengan landasan yang lebih komprehensif.

\section{Implementasi Pengembangan Materi PAI MI dari Persepektif} Integrasi Interkoneksi

Seperti telah disampaikan sebelumnya, bahwa iplementasi pengembangan materi PAI MI perspektif integrasi interkoneksi dapat dilakukan secara internal maupun eksternal.

a. Integrasi Interkoneksi Internal

Integrasi Interkoneksi Internal dilakukan dengan memadukan atau mencari titik temu diantara mata pelajaran yang ada dalam rumpun PAI yaitu : al-Qur'an Hadits, Aqidah, Akhlak, Fiqih dan Tarikh. Sebagai contoh, berikut ini adalah Standar Kompetensi dan Kompetensi Dasar (SK-KD) PAI MI tahun 2006 kelas IV Semester 2 :

\begin{tabular}{|l|l|}
\hline \multicolumn{1}{|c|}{ Standar Kompetensi } & \multicolumn{1}{c|}{ Kompetensi Dasar } \\
\hline Al Qur'an; 6. Membaca & 6.1 Membaca QS Al-Kautsar \\
surat-surat Al Qur'an & $\begin{array}{l}\text { dengan lancar } \\
\text { 6.2 Membaca QS An-Nashr } \\
\text { dengan lancar }\end{array}$ \\
\hline
\end{tabular}




\begin{tabular}{|l|l|}
\hline \multicolumn{1}{|c|}{ Standar Kompetensi } & \multicolumn{1}{c|}{ Kompetensi Dasar } \\
\hline & $\begin{array}{l}\text { 6.3 Membaca QS Al-'Ashr } \\
\text { dengan lancar }\end{array}$ \\
\hline $\begin{array}{l}\text { Aqidah; 7. Mengenal } \\
\text { Malaikat dan tugasnya }\end{array}$ & $\begin{array}{l}\text { 7.1 Menjelaskan pengertian } \\
\text { Malaikat } \\
\text { 7.2 Menyebutkan nama-nama } \\
\text { Malaikat } \\
\text { 7.3 Menyebutkan tugas-tugas } \\
\text { Malaikat }\end{array}$ \\
\hline $\begin{array}{l}\text { Tarikh; 8. Menceritakan } \\
\text { kisah Nabi }\end{array}$ & $\begin{array}{l}\text { 8.1 Menceritakan kisah Nabi } \\
\text { Ibrahim AS }\end{array}$ \\
$\begin{array}{l}\text { 8.2 Menceritakan kisah Nabi } \\
\text { Ismail AS }\end{array}$ \\
\hline $\begin{array}{l}\text { Akhlak; 9. Membiasakan } \\
\text { perilaku terpuji }\end{array}$ & $\begin{array}{l}\text { 9.1 Meneladani perilaku Nabi } \\
\text { Ibrahim AS } \\
9.2 \text { Meneladani Nabi Ismail AS }\end{array}$ \\
\hline $\begin{array}{l}\text { Fiqih; 10. Melaksanakan } \\
\text { dzikir dan do'a }\end{array}$ & $\begin{array}{c}10.1 \quad \text { Melakukan dzikir } \\
\text { setelah shalat }\end{array}$ \\
$\begin{array}{l}10.2 \text { Membaca do'a setelah } \\
\text { shalat }\end{array}$ \\
\hline
\end{tabular}

Untuk mengintegrasikan kelima SK-KD dari mata pelajaran dalam rumpun PAI MI di atas terlebih dahulu dicari titik temu. Jika dilihat, untuk mapel Tarikh dan Aqidah sudah sangat jelas keterkaitannya, yaitu menceritakan kisah Nabi Ibrahim dan Nabi Ismail (Tarikh) dan Meneladani Perilaku Nabi Ibrahim dan Ismail (Aqidah). Kemudian dalam SK-KD mapel Qur'an ditemukan KD membaca QS Al-Kautsar. Dalam QS AlKautsar ini terdapat perintah untuk berqurban yang merupakan napak tilas dari kisah Nabi Ibrahim yang mendapat perintah dari Allah untuk menyembelih Nabi Ismail.

QS Al-Kautsar ayat 1 dan 2 menerangkan bahwa Allah telah memberikan nikmat yang banyak juga perintah untuk 
mendirikan Shalat. Mengenai nikmat yang banyak diberikan Allah, ini dapat dikaitkan dengan tugas-tugas malaikat. Misalnya saja tugas Malaikat Mikail yang sering disebutkan mempunyai tugas menurunkan hujan dan membagi rezeki. Selain itu tugas malaikat Raqib dan Atid untuk mencatat amal baik dan buruk dapat dikaitkan dengan SK-KD Aqidah, yakni meneladani perilaku Nabi Ibrahim dan Ismail yang terpuji. Sedangkan perintah mendirikan shalat dapat dikaitkan dengan SK-KD Fiqih, yakni melakukan Dzikir dan Doa setelah Shalat. Selain itu sebagai pengembangan dapat ditemukan Doa dari Nabi Ibrahim yang diabadikan dalam Al-Qur'an, yakni dalam QS Ibrahim 14: 35,40, dan 41.

Langkah selanjutnya yakni melakukan pengembangan materi. Meminjam prinsip dalam pembelajaran tematik, tema dapat menjadi alat pemersatu beberapa mata pelajaran atau bahan kajian. "Dalam terminologi kurikulum lintas bidang studi, tema yang demikian sering disebut sebagai pusat acuan dalam proses pembauran atau pengintegrasian sejumlah mata pelajaran"18. Dengan menentukan tema yang mampu mengakomodasi berbagai keterkaitan antar beberapa mata pelajaran, maka pengembangan materi yang dilakukan nanti dapat terlihat jelas integrasinya. Memperhatikan uraian sebelumnya mengenai keterkaitan materi, maka tema yang dapat diajukan adalah ketaatan pada Allah. Tema ini juga sesuai dengan konsep integrasi interkoneksi dimana materi PAI dikembangkan untuk membentuk kepribadian muslim anak didik.

18 Departemen Agama, Pedoman Pelaksanaan Pembelajaran Tematik, Jakarta: Direktoran Jenderal Kelembagaan Agama Islam, 2005, hlm. 14.

128 MAGISTRA - Volume 8 Nomor 2 Desember 2017 
Berdasarkan pemaparan di atas, maka pengembangan materi yang dapat dilakukan diantaranya:

1) Dalam Mata Pelajaran Qur'an:

a) Untuk KD membaca QS Al-Kautsar dengan lancar dapat ditambahkan dengan mengetahui artinya.

b) Guru juga dapat menyampaikan keterkaitan antara perintah Qurban yang terdapat pada ayat kedua dengan kisah Nabi Ibrahim.

c) Guru mengaitkan pembelajaran dalam mata pelajaran Qur'an ini dengan Ketaatan Nabi Ibrahim. Dapat pula dikaitkan dengan pelaksanaan Shalat sebagai salah satu wujud ketaatan kepada Allah.

2) Dalam Mata Pelajaran Aqidah:

a) Dalam KD, Menyebutkan tugas-tugas malaikat. Malaikat Mikail yang bertugas mengatur falaq cakrawala ${ }^{19}$, atau sering juga disebutkan bertugas menurunkan hujan dan membagi Rizki dapat ditambahkan tinjauan dari Al-Qur'an, misalnya QS An Naba' ayat 14-16, yang artinya “Dan kami turunkan dari awan air yang banyak tercurah" (14),"Supaya kami tumbuhkan dengan air itu biji-bijian dan tumbuh-tumbuhan" (15), "Dan kebun-kebun yang lebat" (16).

b) Kaitannya dengan ketaatan kepada Allah, anak didik dapat diberikan pemahaman bahwa rezeki Allah begitu banyak dilimpahkan sehingga ketaatan kepada Allah adalah kewajiban yang sebenarnya menjadi kebutuhan anak didik. Ini juga dapat dikaitkan dengan tugas Maliakat Raqib dan hlm. 118.

${ }^{19}$ Hamka, Pelajaran Agama Islam, Cet IX, Jakarta: PT Bulan Bintang, 1987, 
Atid yang mencatat segala amal baik dan buruk yang dilakukan manusia.

3) Dalam Mata Pelajaran Tarikh:

a) Dalam KD disebutkan Menceritakan kisah Nabi Ibrahim AS dan Nabi Ismail AS. Untuk KD ini dapat diarahkan pada kisah Nabi Ibrahim yang mendapatkan perintah dari Allah untuk menyembelih Nabi Ismail. Materi ini hendaknya menekankan pada begitu besarnya Ketaatan dan Keikhlasan Nabi Ibrahim serta Nabi Ismail kepada Allah.

b) Sebagai tambahan dapat disampaikan pula kaitan kisah tersebut dengan perintah qurban yang terdapat dalam QS Al-Kautsar.

4) Dalam Mata Pelajaran Akhlak:

a) Dalam KD disebutkan; meneladani perilaku Nabi Ibrahim AS. Mengenai perilaku Nabi Ibrahim yang dapat diteladani adalah mau mengorbankan sesuatu yang sangat dicintainya untuk membuktikan ketaatan dan kecintaannya kepada Allah yang melebihi apapun.

b) Kaitannya dengan pengembangan materi hubungannya dengan meneladani perilaku Nabi Ibrahim dan Ismail dapat diarahkan dalam bersedekah/berinfak. Dapat juga dengan Shalat dengan tepat waktu (terkait dengan KD mapel Qur'an mengenai QS Al-Kautsar tentang perintah mendirikan Shalat).

5) Dalam Mata Pelajaran Fiqih:

a) Untuk KD Membaca Doa setelah Shalat, materi dapat dikembangkan dengan doa-doa yang dari Nabi Ibrahim 
yang terdapat dalam Al-Qur'an, misalnya dalam QS Ibrahim 14: ayat 35,40 dan 41 :

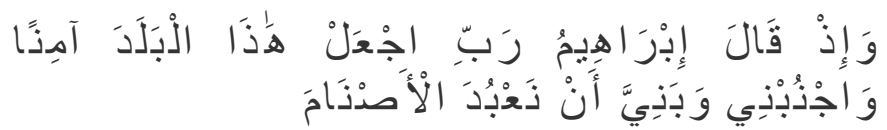

Artinya: ...."Ya Tuhanku, jadikanlah negeri Ini (Mekah), negeri yang aman, dan jauhkanlah Aku beserta anak cucuku daripada menyembah berhalaberhala.

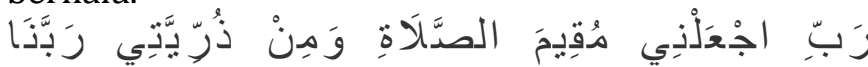

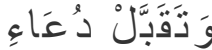

Artinya: Ya Tuhanku, jadikanlah Aku dan anak cucuku orang-orang yang tetap mendirikan shalat, Ya Tuhan kami, perkenankanlah doaku.

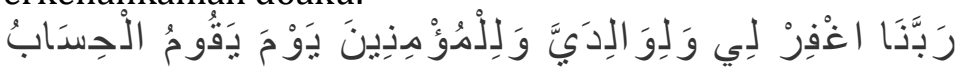

Artinya: Ya Tuhan kami, beri ampunlah Aku dan kedua ibu bapaku dan sekalian orang-orang mukmin pada hari terjadinya hisab (hari kiamat)".

b. Implementasi Integrasi Interkoneksi Eksternal

Implementasi Integrasi Interkoneksi Eksternal dilakukan dengan menyatukan atau mempertemukan antar materi dalam rumpun PAI dengan materi mata pelajaran Sain. Dengan integrasi-interkoneksi eksternal ini, kebenaran wahyu yang ada dalam PAI diharapkan dapat didukung dengan tinjauan ilmiah yang ada dalam materi Sain/IPA. Jika hal ini dapat dilakukan maka diharapkan anak didik akan semakin kuat nilai spiritual Islamnya dengan landasan yang lebih komprehensif.

Sebagai contoh, berikut ini SK-KD IPA tahun 2006 kelas IV Semester 2 tentang Bumi dan alam Semesta : 


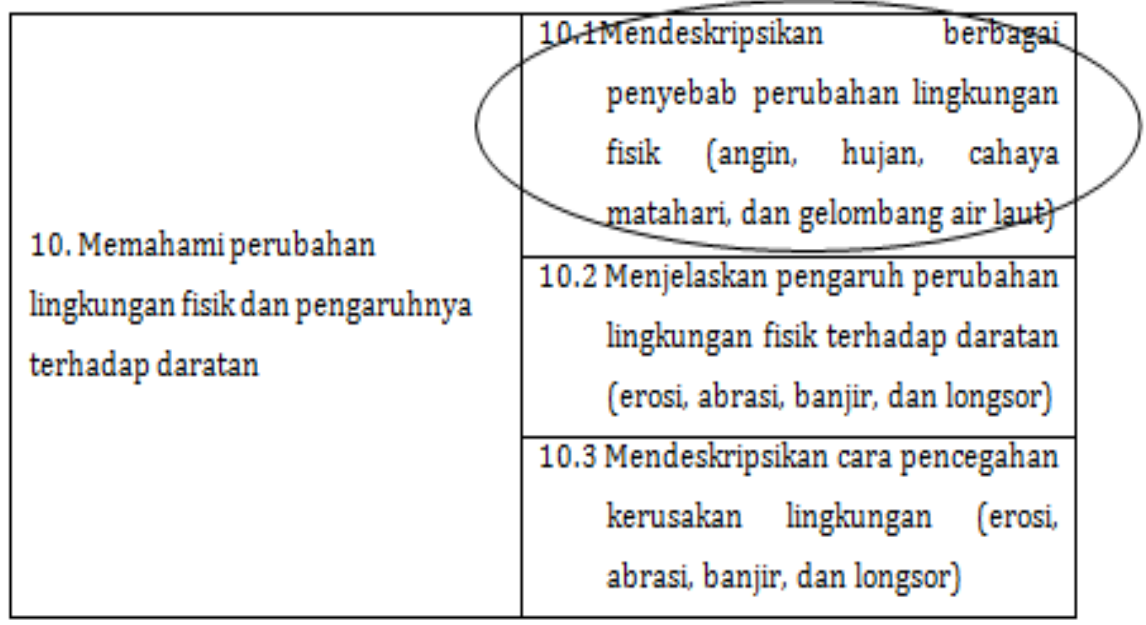

Dalam SK-KD PAI Kelas IV Semester 2, dalam mata pelajaran Akidah Akhlak tentang tugas malaikat, telah disinggung tentang Malaikat Mikail yang bertugas menurunkan hujan dan membagi rizki. Tentang turunnya hujan dibahas dalam mata pelajaran IPA, seperti dapat dilihat dalam SK-KD IPA diatas.

Dalam kajian IPA, hujan terjadi dari uap air/air laut yang menguap karena panas matahari yang kemudian menguap naik menjadi awan. Awan tersebut kemudian akan mencair dan terjadilah hujan. Untuk mengintegrasi dan menginterkoneksikan tinjauan ilmiah ini materi PAI yang ada dapat dikembangkan dengan menambahkan kajian tentang surat An Naba' ayat 13 dan 14, yang berbunyi :

$$
\text { وَجَعَلْنَا سِرَ اجِا وَهَّاجِا }
$$

Artinya: Dan kami jadikan Pelita yang amat terang (matahari),

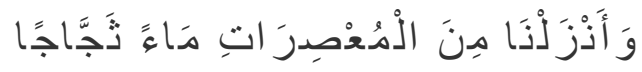

Artinya: Dan kami turunkan dari awan air yang banyak tercurah,

132 MAGISTRA - Volume 8 Nomor 2 Desember 2017 
Pengembangan materi dengan menampilkan QS An Naba' diatas dapat memberikan pemahaman bahwa Allah menurunkan hujan juga melalui prosedur alamiah. Selain itu, penjelasan ilmiah mengenai terjadinya hujan juga dapat ditemui dalam Al-Qur'an.

Contoh lain, berikut ini SK-KD MI Kelas VI Semester 1 pada mata pelajaran PAI Al-Qur'an dan IPA :

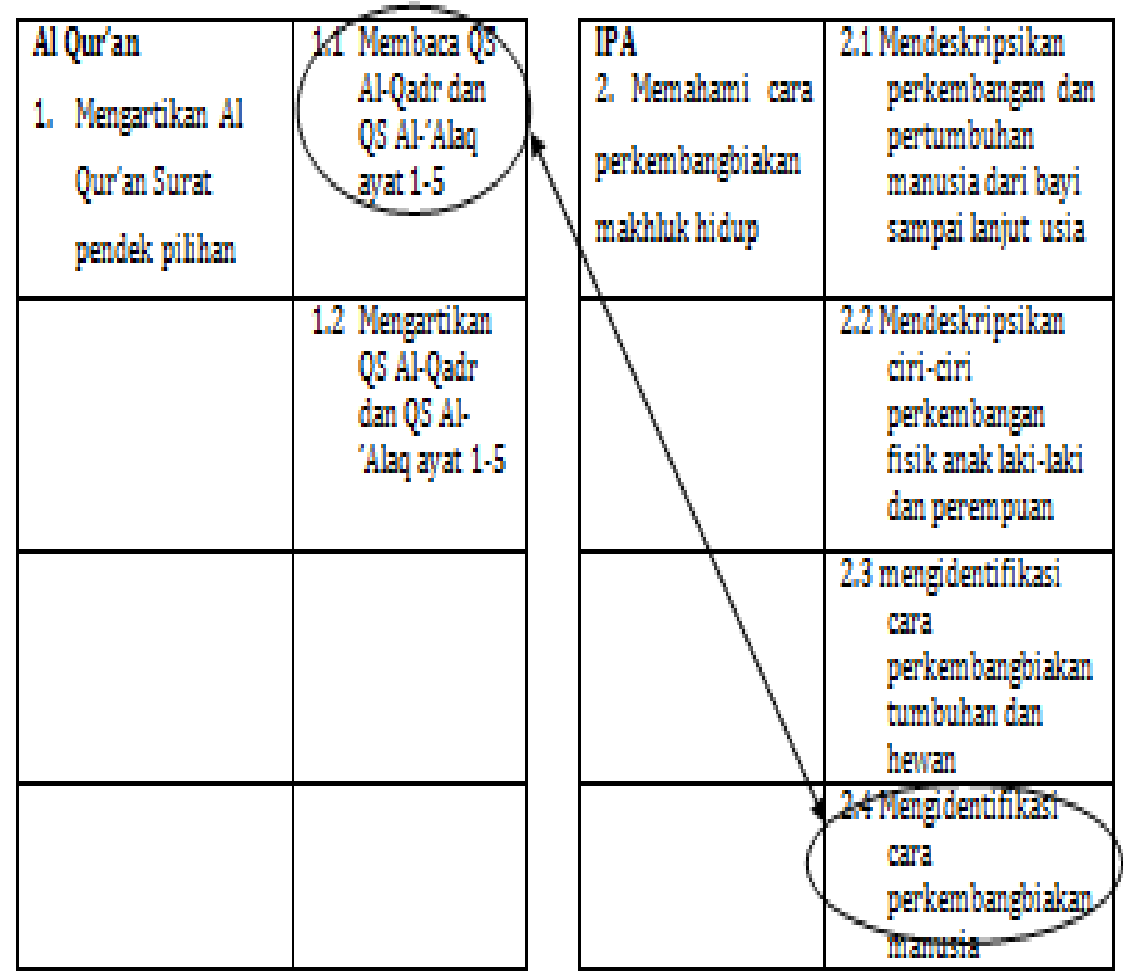

penciptaan manusia oleh Allah (dalam PAI Qur'an) dan perkembangbiakan manusia (dalam IPA). Dalam QS Al alaq ayat 2 disebutkan:

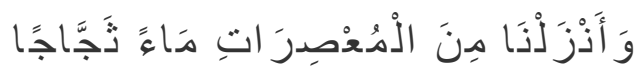

133 MAGISTRA - Volume 8 Nomor 2 Desember 2017 
Artinya: Dia Telah menciptakan manusia dari segumpal darah.

Pada kajian IPA reproduksi/perkembangbiakan manusia dimulai dengan pembuahan ovum oleh sperma. Untuk lebih memperjelas keterkaitan antara materi PAI dan IPA diatas, pengembangan materi PAI Qur'an dapat dilakukan dengan menambahkan kajian QS Ar-Rum 20, yang artinya:

"Dan di antara tanda-tanda kekuasaan-Nya ialah dia menciptakan kamu dari tanah, Kemudian tiba-tiba kamu (menjadi) manusia yang berkembang biak."

Tentang ayat tersebut, Ibn Kasir menafsirkan basyarun tantansyirun (manusia yang berkembang biak) pada ayat diatas, bahwa manusia berasal dari tanah, atau memakan makanan yang dihasilkan dari bercocok tanam, kemudian sari pati makanan itu menjadi sperma yang dipertemukan dengan ovum wanita, hasil pertemuan itu kemudian berubah menjadi segumpal darah dan beberapa hari kemudian berubah menjadi segumpal daging. Segumpal daging itu kemudian berubah menjadi tulang belulang, kemudian tulang-belulang dibungkus dengan daging. Setelah itu, Allah meniupkan ruh ke dalamnya ${ }^{20}$. Dengan tafsir dari Ibn Kasir ini, penjelasan dari ayat Al-Qur'an bahwa Allah menciptakan manusia dari tanah dapat ditemukan kesesuannya dalam kajian ilmiah. Proses kejadian manusia yang berawal dari materi (tanah dan air)

20 Munawir Sjadzali, Chamamah Soeratno, dkk (ed), Enslikopedi Al-Qur'an, Yogyakarta: PT Dana Bhakti Prima Yasa, 2002, hlm. 329.

134 MAGISTRA - Volume 8 Nomor 2 Desember 2017 
dan imateri (ruh) ini antara lain dijelaskan pula dalam QS. Al Mukminun 12-14 dan QS. As Sajdah ayat 7-9.21

\section{SIMPULAN}

Istilah dikotomi ilmu adalah sikap atau paham yang membedakan, memisahkan, dan mempertentangkan antara ilmu-ilmu agama dan ilmu-ilmu non agama (ilmu umum). Pendidikan agama melalui madrasah, institut agama, dan pesantren dikelola oleh Departemen Agama, sedangkan pendidikan umum melalui sekolah dasar, sekolah menengah, dan kejuruan serta perguruan tinggi umum dikelola oleh Departemen Pendidikan Nasional. Pendidikan Islam tidak semata-mata mengajarkan pengetahuan Islam secara teoritik sehingga hanya menghasilkan seorang Islamolog, tetapi pendidikan Islam juga menekankan pada pembentukan sikap dan perilaku yang Islami.

Adapun implikasi adanya dikotomi pendidikan, yaitu: munculnya ambivalensi orientasi pendidikan Islam, kesenjangan antar sistem pendidikan Islam dan ajaran Islam, disintegrasi system pendidikan Islam. Implementasi pengembangan materi PAI di MI merupakan salah satu alternative untuk mengatasi terjadinya dikotomi pendidikan atau pengetahuan. Integrasi-Interkoneksi dapat dilakukan dengan cara internal rumpun mata pelajaran PAI atau dengan eksternal mata pelajaran IPA. Jika Implementasi Pengembangan Materi PAI di MI Persepektif Integratif Interkonektif dapat dilakukan maka anak didik akan memiliki pengetahuan yang lebih komprehensif baik mata pelajaran IPA maupun mata pelajaran PAI. Pemahaman anak tentang

21 Mustafa Anshori Lidinilah dkk, Pendidikan Agama Islam, Cet II, Yogyakarta: Badan Penerbitan Filsafat UGM, 2006, hlm. 25.

135 MAGISTRA - Volume 8 Nomor 2 Desember 2017 
kedua materi IPA dan PAI juga akan semakin jelas dengan model integratif-interkonektif tersebut. 


\section{DAFTAR PUSTAKA}

Abd. Rachman Assegaf "Pengantar" dalam: Jasa Ungguh Muliawan, Pendidikan Islam Integratif, Yogyakarta: Pustaka Pelajar, 2005.

Ahmad Asy'ari dan Rusnil Bil Makruf, Dikotomi Prndidikan Islam, el-Hikmah Jurnal kajian dan Penelitian Pendidikan Islam, Vol.8 No.2 Desember 2014.

ANN C. HOWE \& Linda Jones, Children In science; (Integrating Science With Other Subjects), (New York: Macmillan Publishing Company, 1993), hlm. 219-230.

Departemen Agama, Pedoman Pelaksanaan Pembelajaran Tematik, Jakarta: Direktoran Jenderal Kelembagaan Agama Islam, 2005.

Hamka, Pelajaran Agama Islam, Cet IX, Jakarta: PT Bulan Bintang, 1987.

Jasa Ungguh Muliawan, Pendidikan Islam Integratif, Yogyakarta: Pustaka Pelajar, 2005.

M. Quraish Shihab, Wawasan Al-Qur'an, Cet III,Bandung: Mizan, 1996.

M. Zainuddin. Paradigma Pendidikan Terpadu, Menyiapkan Generasi Ulul Albab, UIN-Malang Press, Malang, 2008.

Maya Fitria, Psikologi Integrasi Interkoneksi, dalam Keilmuan, Integrasi dan Interkoneksi Bidang Agama dan Sosial, Yogyakarta: Lembaga Penelitian UIN Sunan Kalijaga, 2007.

Melani Kasim, Pembelajaran Terpadu, Makalah "Pembelajaran Terpadu" «Meilanikasim's Blog.htm.

Muhaimin, Wacana Pengembangan Pendidikan Islam, Cet II, Yogyakarta: Pustaka Pelajar, 2004.

Mujammil Qamar, EpistemologiPendidikan Islam, Erlangga, Jakarta, 2006.

Munawir Sjadzali, Chamamah Soeratno, dkk (ed), Enslikopedi Al-Qur'an, Yogyakarta: PT Dana Bhakti Prima Yasa, 2002.

Mustafa Anshori Lidinilah dkk, Pendidikan Agama Islam, Cet II,Yogyakarta: Badan Penerbitan Filsafat UGM, 2006.

137 MAGISTRA - Volume 8 Nomor 2 Desember 2017 
Pokja Akademik UIN Sunan Kalijaga,2004.

Rizal Mustansyir dan Misnal Munir, Filsafat Ilmu, Cet IX, Yogyakarta: Pustaka Pelajar, 2009.

Sutrisno, Pendidikan Islam Yang Menghidupkan, Cet II, Yogyakarta: Kota Kembang, 2008.

Tim Penyusun Kamus Pusat Bahasa, Kamus Besar Bahasa Indonesia, BalaiPustaka, Jakarta, 2001. 